University of Montana

ScholarWorks at University of Montana

Ecosystem and Conservation Sciences Faculty

Publications

Ecosystem and Conservation Sciences

2009

\title{
Controls Over Leaf Litter Decomposition in Wet Tropical Forests
}

William R. Wieder

Cory C. Cleveland

The University of Montana, cory.cleveland@umontana.edu

Alan R. Townsend

Follow this and additional works at: https://scholarworks.umt.edu/decs_pubs

Part of the Ecology and Evolutionary Biology Commons

Let us know how access to this document benefits you.

\section{Recommended Citation}

Wieder, William R.; Cleveland, Cory C.; and Townsend, Alan R., "Controls Over Leaf Litter Decomposition in Wet Tropical Forests" (2009). Ecosystem and Conservation Sciences Faculty Publications. 15.

https://scholarworks.umt.edu/decs_pubs/15

This Article is brought to you for free and open access by the Ecosystem and Conservation Sciences at ScholarWorks at University of Montana. It has been accepted for inclusion in Ecosystem and Conservation Sciences Faculty Publications by an authorized administrator of ScholarWorks at University of Montana. For more information, please contact scholarworks@mso.umt.edu. 


\title{
Controls over leaf litter decomposition in wet tropical forests
}

\author{
William R. Wieder, ${ }^{1,3}$ Cory C. Cleveland, ${ }^{2}$ and Alan R. Townsend ${ }^{1}$ \\ ${ }^{1}$ Institute for Arctic and Alpine Research (INSTAAR) and Department of Ecology and Evolutionary Biology, \\ University of Colorado, Boulder, Colorado 80309 USA \\ ${ }^{2}$ College of Forestry and Conservation, University of Montana, Missoula, Montana 59812 USA
}

\begin{abstract}
Tropical forests play a substantial role in the global carbon (C) cycle and are projected to experience significant changes in climate, highlighting the importance of understanding the factors that control organic matter decomposition in this biome. In the tropics, high temperature and rainfall lead to some of the highest rates of litter decomposition on earth, and given the near-optimal abiotic conditions, litter quality likely exerts disproportionate control over litter decomposition. Yet interactions between litter quality and abiotic variables, most notably precipitation, remain poorly resolved, especially for the wetter end of the tropical forest biome. We assessed the importance of variation in litter chemistry and precipitation in a lowland tropical rain forest in southwest Costa Rica that receives $>5000 \mathrm{~mm}$ of precipitation per year, using litter from 11 different canopy tree species in conjunction with a throughfall manipulation experiment. In general, despite the exceptionally high rainfall in this forest, simulated throughfall reductions consistently suppressed rates of litter decomposition. Overall, variation between species was greater than that induced by manipulating throughfall and was best explained by initial litter solubility and lignin:P ratios. Collectively, these results support a model of litter decomposition in which mass loss rates are positively correlated with rainfall up to very high rates of mean annual precipitation and highlight the importance of phosphorus availability in controlling microbial processes in many lowland tropical forests.
\end{abstract}

Key words: decomposition; dissolved organic matter (DOM); leaching; litter chemistry; nutrient limitation; phosphorus; precipitation; throughfall manipulation; tropical rain forest.

\section{INTRODUCTION}

Litter decomposition is a fundamental ecosystem process, and a rich history of research shows that climate and litter chemistry strongly control rates of litter decay (Meentemeyer 1978, Swift et al. 1979, Melillo et al. 1982, Hobbie 1996, Adair et al. 2008). Across multiple ecosystem types, temperature, indices of water availability, and measures of litter quality, such as nitrogen $(\mathrm{N})$ availability, lignin content, or lignin:N ratios, are useful for predicting rates of mass loss (Vitousek et al. 1994, Aerts 1997, Potter and Klooster 1997, Gholz et al. 2000). Recent syntheses even suggest a remarkable global consistency in the predominant controls over decomposition, leading to the sense that litter decomposition is one key ecosystem process that is well understood (Gholz et al. 2000, Parton et al. 2007).

Nonetheless, there is reason to believe that relationships observed in many ecosystems may not hold in extremely wet tropical forests, where the interplay of climate and litter chemistry in controlling litter decomposition remains poorly understood (Cleveland et al. 2006). For example, studies at multiple scales have

Manuscript received 12 December 2008; revised 6 March 2009; accepted 2 April 2009. Corresponding Editor: J. B. Yavitt.

${ }^{3}$ E-mail: will.wieder@colorado.edu shown that increasing temperature and precipitation frequently correlate with accelerated rates of litter decomposition (Wieder and Wright 1995, Austin and Vitousek 2000, Gholz et al. 2000). Yet many lowland tropical forests experience little or no diurnal or seasonal temperature variation, while precipitation frequently exceeds levels that maximize forest productivity (i.e., Schuur 2003). However, the effects of precipitation on decomposition in sites that occupy the high end of the tropical precipitation spectrum (i.e., $>2500 \mathrm{~mm} / \mathrm{yr}$ ) are underrepresented in the literature. Schuur (2001) suggested that mean annual precipitation (MAP) above this amount leads to episodic soil saturation that increases anoxia and slows decomposition. In contrast, Cleveland et al. (2006) proposed that in very wet tropical forests, physical leaching of dissolved organic matter (DOM) may increase with precipitation, causing more rapid rates of mass loss as precipitation levels rise. Though the potential importance of physical processes in controlling litter decomposition is still not widely recognized, leaching is an important component of some decomposition models, one that can lessen nutrient limitation of litter decomposition and depends on the solubility of plant matter being decomposed (Currie and Aber 1997, Neff and Asner 2001, Allison and Vitousek 2004).

Climate is not the only factor that likely controls variation in DOM leaching in tropical forests. This biome also exhibits extraordinary species diversity, 
leading to significant local- and regional-scale variation in leaf chemical traits that are likely to influence litter solubility and rates of decomposition (Scherer-Lorenzen et al. 2007, Cornwell et al. 2008, Townsend et al. 2008, Wieder et al. 2008). In addition, while indices of $\mathrm{N}$ availability are useful predictors of litter decomposition in multiple biomes (Gholz et al. 2000, Parton et al. 2007), $\mathrm{N}$ cycles in relative excess in much of the lowland tropics (Martinelli et al. 1999) but low soil P availability and high litter C:P ratios are common (Vitousek and Sanford 1986). Thus, while both climate and litter chemistry likely regulate litter decomposition in tropical forests just as they do throughout the world, the mechanisms underlying that control may play out quite differently than in drier biomes.

Understanding how climate-chemistry interactions regulate tropical forest litter decomposition is of particular interest because of the potential for large rainfall shifts that may influence rates of carbon (C) exchange and storage. Lowland tropical rain forests have globally important effects on the terrestrial C cycle (Dixon et al. 1994, Field et al. 1998), and fine litterfall accounts for $\sim 60 \%$ of aboveground net primary productivity (ANPP) in this biome (Clark et al. 2001). Many climate change models predict strong changes in MAP over tropical latitudes, but the direction of these changes is both regionally dependent and often uncertain (Meehl et al. 2007). The extent to which ecosystem $\mathrm{C}$ balance may be influenced by precipitation-mediated changes in decomposition also remains uncertain (Tian et al. 1998, Schuur 2001, Saleska et al. 2003, Clark 2004). This statement is particularly true for the wettest portions of the tropical biome.

In this study, we used natural variations in species litter chemistry, combined with a throughfall removal experiment to investigate the effects of litter quality and precipitation on litter decomposition in a lowland tropical rain forest. Manipulations of MAP have been conducted in tropical forests at the dry end of the evergreen forest precipitation spectrum $(<2500 \mathrm{~mm} / \mathrm{yr}$; e.g., Yavitt et al. 1993, Nepstad et al. 2002), but our aim was to explore the effects of precipitation in a site where MAP greatly exceeds the theoretical precipitation optimum hypothesized by Schuur (2001, 2003). Our goals were to test the hypothesis that precipitationdriven DOM fluxes are a significant litter mass loss vector (Cleveland et al. 2006) and to understand the relative effects of litter chemistry vs. throughfall on rates of litter decomposition. Our initial hypothesis was that DOM leaching would be a major vector for litter mass loss and hence reducing throughfall would likewise reduce rates of decomposition via declines in leached DOM. Finally, we conducted this study in a site where P limitation of microbial processes is well documented (Cleveland et al. 2002, Cleveland and Townsend 2006, Reed et al. 2007, Wieder et al. 2008) and therefore hypothesized that litter $\mathrm{P}$ content might be an important control over rates of decomposition, especially in later stages of decomposition when we expected the relative importance of litter solubility and DOM leaching to decline.

\section{Methods \\ Site description}

The research site is a diverse, mature, lowland tropical rain forest located on the Osa Peninsula in the Golfo Dulce Forest Reserve in southwest Costa Rica $\left(8^{\circ} 43^{\prime} \mathrm{N}\right.$, $83^{\circ} 37^{\prime} \mathrm{W}$ ). The entire Osa Peninsula has $\sim 750$ species of canopy tree species (Quesada et al. 1997), and at our study site estimated canopy tree diversity is 100-200 species/ha (Kappelle et al. 2003). Mean annual temperature at the site is $26.5^{\circ} \mathrm{C}$, and mean annual precipitation averages $>5000 \mathrm{~mm} / \mathrm{yr}$. Precipitation averages $>500$ $\mathrm{mm} /$ month from May to November and peak rainfall occurs between June and October (Cleveland and Townsend 2006). A short dry season between December and April coincides with high leaf senescence and maximum annual litterfall (Cleveland et al. 2006). Soils at the site have been classified as Ultisols (for more detailed soil information see Bern et al. [2005], Cleveland et al. [2006], and Cleveland and Townsend [2006]).

\section{Experimental design}

To manipulate precipitation, we constructed throughfall exclosures. Briefly, $5 \mathrm{~cm}$ diameter PVC pipes were cut longitudinally and mounted on $2.4 \times 2.4 \mathrm{~m}$ aluminum frames $\sim 1 \mathrm{~m}$ above the soil surface. The PVC pipes acted as partial rain sheds, shielding $2 \times$ $2 \mathrm{~m}$ experimental plots from receiving full incoming throughfall. The PVC pipes were mounted at either 5-cm or $15-\mathrm{cm}$ intervals to simulate $50 \%$ or $25 \%$ reductions in throughfall. Twenty randomly assigned plots received $50 \%$ or $25 \%$ throughfall exclosures $(N=10$ per treatments), and an additional 10 plots served as experimental controls. To document the amount of water passing through the litter layer, each plot was instrumented with a zero tension PVC lysimeter $(10.5 \times$ $50 \mathrm{~cm}$ ) installed flush with the soil surface and below the litter layer. Water intercepted from the litter layer was collected in plastic vessels and the volume was determined gravimetrically every four days. We also quantified precipitation with a rain gauge in a clearing $\sim 400 \mathrm{~m}$ from the study site. Plots were purposefully not trenched so that the throughfall manipulation would be concentrated on the litter-soil interface without significantly altering soil moisture or root biomass; data from the plots (not shown here) confirm no significant changes in these variables across the manipulations.

Recently senesced litter was collected from 11 canopy tree species (see Table 1; Brosimum utile [Moraceae], Cecropia obtusifolia [Cecropiaceae], Ceiba pentandara [Bombacaceae], Huberodendron allenii [Bombacaceae], Hyeronima alchorneoides [Euphorbiaceae], Inga spp. [Fabaceae/Mim], Manilikara staminodella [Sapotaceae], Pouteria lecythidicarpa [Sapotaceae], Qualea paraensis [Vochysiaceae], Schizolobium parahyba [Fabaceae/ 
Caes.], and Symphonia globulifera [Clusiaceae]). From this point forward we refer to genus names to avoid confusion. Individual species and bulk litter samples were collected between November 2006 and March 2007, air dried, and homogenized because our primary interest in species was to capture chemical and physical litter variation. Approximately $5 \mathrm{~g}$ of litter was sealed in $15 \times 15 \mathrm{~cm}$ litterbags constructed with $1-\mathrm{mm}$ mesh fiberglass screen. Additional litter samples were immediately returned to the laboratory, dried at $60^{\circ} \mathrm{C}$ for four days, weighed to determine dry mass conversions, and analyzed for initial litter chemistry.

In April 2007 (at the end of the dry season, and when forest floor litter mass is highest; Cleveland et al. 2006), a total of 1008 litterbags were placed on the surface of the standing litter layer in six of each of the throughfall manipulation and control plots. Bags were separated on strands by at least $15 \mathrm{~cm}$. Control plots received litterbags made from all 11 species and bulk litter. Because of space limitation in treatment plots, $50 \%$ and $25 \%$ throughfall reduction plots received litterbags made from Brosimum, Manilikara, Qualea, Schizolobium, Symphonia, and bulk litter. These species were chosen because we had more information regarding their initial litter chemistry (Wieder et al. 2008). Subsequently, litterbags were harvested after 28, 51, 93, 135, 165, 200 , and $230 \mathrm{~d}$.

\section{Analytical methods}

Following collection, initial litter samples and decomposition bags were air-dried in the field and returned to the laboratory at the University of Colorado. After removing adhered debris with a dry brush, bags were dried at $60^{\circ} \mathrm{C}$ for four days and reweighed to determine mass loss at each time interval. Approximately $10 \mathrm{~g}$ of the initial oven-dried litter samples were ground to a fine powder with Wiley mill (40 mesh) used in subsequent chemical analyses. Litter percentage of carbon $(\% \mathrm{C})$ and percentage of nitrogen $(\% \mathrm{~N})$ were determined using a Carlo Erba EA 1110 elemental analyzer (CE Elantech, Lakewood, New Jersey, USA). Litter P was assessed using a sulfuric acid/hydrogen peroxide digest and a colorimetric $\mathrm{P}$ analysis on an Alpkem autoanalyzer (OI Analytical, College Station, Texas, USA) using the ammonium molybdate ascorbic acid method (Kuo 1996). Litter solubility and $\mathrm{C}$ fractions of decomposing organic matter were determined using a plant fiber analyzer (Ankom Technology, Macedon, New York, USA). Briefly, initial litter samples were ground to a fine powder, sealed in filter bags, and digested in a dilute neutral detergent at $100^{\circ} \mathrm{C}$. Following digestion, filter bags were dried and reweighed to determine soluble cell mass loss (Hobbie and Gough 2004). Subsequent digestions in acid detergent and sulfuric acid were used to calculate hemicellulose and bound proteins, cellulose, and lignin and "other recalcitrants" fractions.

Because grinding leaves changes their physical state, we also performed solubility experiments on intact
TABle 1. Decomposition constants (per year; mean $\pm \mathrm{SE}$ ) based on exponential $\left(k, k_{2}\right)$ and linear $\left(k_{1}\right)$ decomposition models.

\begin{tabular}{lccc}
\hline \hline \multicolumn{1}{c}{ Taxon } & $k$ & $k_{1}$ & $k_{2}$ \\
\hline Bulk litter & $1.93 \pm 0.12$ & $179.3 \pm 21.6$ & $1.75 \pm 0.17$ \\
Brosimum & $1.31 \pm 0.11$ & $113.5 \pm 17.3$ & $1.32 \pm 0.14$ \\
Cecropia & $0.96 \pm 0.02$ & $93.5 \pm 19.5$ & $1.15 \pm 0.14$ \\
Ceiba & $2.58 \pm 0.09$ & $213.9 \pm 11.5$ & $2.98 \pm 0.14$ \\
Huberodendron & $1.62 \pm 0.07$ & $199.8 \pm 7.4$ & $1.46 \pm 0.07$ \\
Hyeronima & $0.86 \pm 0.07$ & $68.1 \pm 16.8$ & $1.13 \pm 0.11$ \\
Inga & $1.62 \pm 0.10$ & $176.9 \pm 10.8$ & $1.70 \pm 0.16$ \\
Manilikara & $0.99 \pm 0.04$ & $113.9 \pm 9.9$ & $0.99 \pm 0.06$ \\
Pouteria & $1.11 \pm 0.06$ & $117.3 \pm 11.3$ & $1.16 \pm 0.16$ \\
Qualea & $1.13 \pm 0.10$ & $122.7 \pm 20.2$ & $1.22 \pm 0.15$ \\
Schizolobium & $3.24 \pm 0.14$ & $311.2 \pm 5.7$ & $3.34 \pm 0.21$ \\
Symphonia & $2.13 \pm 0.10$ & $175.5 \pm 21.1$ & $2.38 \pm 0.17$ \\
\hline
\end{tabular}

leaves. Cold-water solubility was determined by placing $\sim 5 \mathrm{~g}$ of air-dried litter into sealed flasks with $200 \mathrm{~mL}$ of deionized water and placing flasks on an orbital shaker at room temperature. Initial solubility was determined after $2 \mathrm{~h}$ when $15 \mathrm{~mL}$ of the DOM was removed, filtered, and analyzed for total C using high-temperature combustion (Shimaduzu TOCvepn, Kyoto, Japan). Total solubility was determined after $24 \mathrm{~h}$ when the solution was similarly decanted, filtered, and analyzed. Initial and total solubility are reported as milligrams of C per gram oven-dried litter.

\section{Statistical analyses}

Annual decomposition rates ( $k$ values) were determined by species and throughfall treatment. Mass loss data were analyzed using the negative exponential decay model of Olson (1963), $y=100 e^{-k t}$, where $k$ is the fraction of mass remaining at a specific time $t$ (years). Similarly, we calculated initial decomposition constant $\left(k_{1}\right)$ for each species and throughfall treatment using only litter mass values from $0-50 \mathrm{~d}$ using a linear decomposition model and secondary decomposition constant $\left(k_{2}\right)$ using values from 51-230 d using an exponential decay model. Time points for $k_{1}$ were chosen because we observe significantly higher dissolved organic carbon fluxes out of the litter layer during the first seven to eight weeks of the rainy season (W. R. Wieder, unpublished data) and because of better fit to decomposition models. To normalize species effects in the throughfall treatment, we calculated species-specific response ratios by dividing mean treatment decomposition constants by control decomposition constants.

Total throughfall measured in all plots and differences between species' decomposition constants were compared using one-way analysis of variance (ANOVA, SPSS, Chicago, Illinois, USA). Two-way ANOVA was also used to determine the effect of the throughfall treatment, species, and their interactions on litter decomposition rates. We used stepwise multiple linear regressions with backwards elimination to determine how well variation in litter chemistry predicted observed decomposition constants (Hobbie et al. 2006). These 


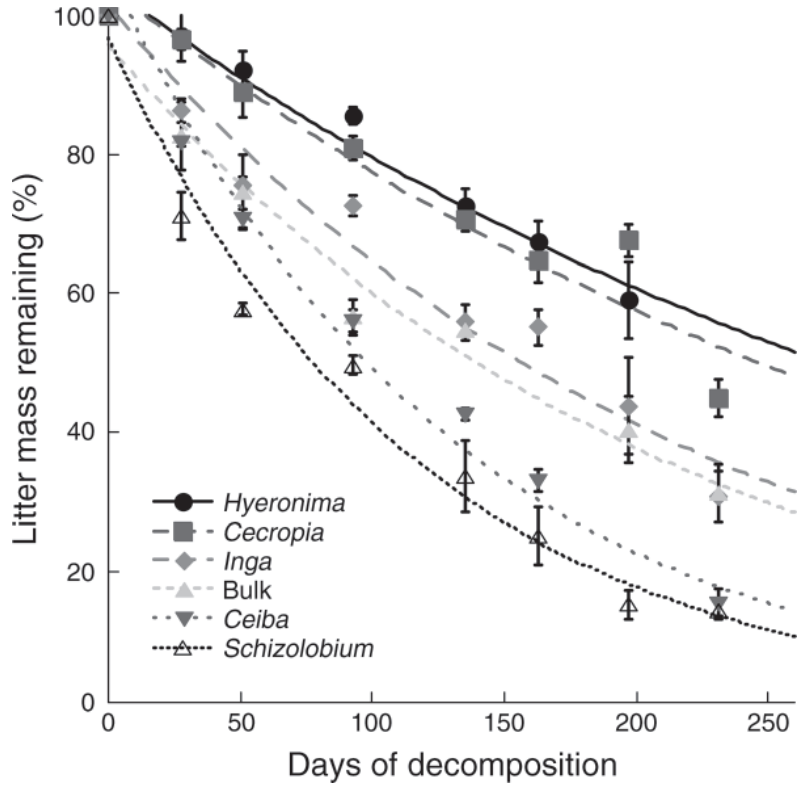

FIG. 1. Decomposition curves from control plots for all time points showing the litter mass remaining (mean $\pm \mathrm{SE}$ ) for taxa selected to show the range of decomposition rates. Decomposition constants $(k)$ were calculated using an exponential decay model fit to data with $R^{2}$ values ranging from 0.72 to 0.99 . Decay constants between species varied by nearly a factor of 4 and were significantly different from one another $\left(F_{11,5}=64.33, P<0.001\right)$.

results guided subsequent simple linear regressions using individual litter characteristics to predict $k_{1}$ and $k_{2}$ values.

\section{RESUlts}

\section{Litter decomposition experiment}

Exponential decay curves for the entire decomposition experiment (0-230 d) described the data well (in all plots mean $R^{2}=0.92$, range $=0.72-0.99$ ). Mass loss rates in all litterbags were rapid, but highly variable between species (Fig. 1). For example, mass loss of Schizolobium litter was $>50 \%$ in $<100 \mathrm{~d}$ and $85 \%$ in $<200 \mathrm{~d}$, while mass loss of Hyeronima litter was $<50 \%$ after 230 days of decomposition. Corresponding decomposition constants $(k)$ for decomposing litter from 11 individual species varied by nearly a factor of four (Table 1 ) and were significantly different from one another $\left(F_{11,5}=\right.$ 64.33, $P<0.001)$. Similarly, initial litter decomposition rates $\left(0-50 \mathrm{~d}, k_{1}\right.$, mean $R^{2}=0.97$, range $\left.=0.70-1\right)$ and secondary litter decomposition constants $\left(50-230 \mathrm{~d}, k_{2}\right.$, mean $R^{2}=0.88$, range $=0.53-1$ ) also showed significant difference between species $\left(k_{1}, F_{5,5}=17.98, P<0.001\right.$; $\left.k_{2}, F_{5,5}=27.39, P<0.001\right)$.

We observed substantial between-species variation in initial litter chemistry (Table 2). For example, among all species, initial $\mathrm{P}$ varied by a factor of 12 , initial lignin:P ratios varied by more than a factor of 8 , and initial litter solubility varied by more than a factor of 5 . We screened independent variables for significant autocorrelation $(r$ $>0.80$ ) and omitted leaf lignin from analyses because of tight correlation with cell soluble fraction $(r=-0.88, P$ $<0.01)$. Total litter $\mathrm{N}$ and litter $\mathrm{P}$ were omitted from regression analyses because of tight correlation with one another and with other parameters (e.g., C:N and C:P; lignin: $\mathrm{N}$ and lignin: $\mathrm{P}, r>0.80, P<0.01)$. Finally, litter $\mathrm{C}: \mathrm{N}$ and lignin: $\mathrm{N}$ were analyzed in separate regressions from C:P and lignin:P because of strong autocorrelation $(r>0.80, P<0.01)$.

We conducted stepwise multiple linear regressions with backward elimination to examine the relationship between litter chemistry and decomposition rates; initial litter solubility $(P=0.04)$ and initial lignin:P $(P=0.02)$ were the best predictors of observed decomposition rates (model $R^{2}=0.72, P=0.003$; Fig. 2a). In similar regressions using $\mathrm{C}: \mathrm{N}$ and lignin: $\mathrm{N}$ as predictors (instead of autocorrelates $\mathrm{C}: \mathrm{P}$ and lignin:P), initial litter $\mathrm{C}: \mathrm{N}(P=0.01)$ and initial percentage of cellulose $(P=$ 0.03 ) predicted observed $k$ values (model $R^{2}=0.66, P=$ $0.008)$. Initial litter solubility was the best single predictor for observed $k_{1}$ values $\left(R^{2}=0.60, P=0.003\right.$; Fig. 2b). Initial lignin:P was the best single predictor for

TABLE 2. Initial litter chemistry for 11 taxa and bulk litter used in litter decomposition experiment.

\begin{tabular}{|c|c|c|c|c|c|c|c|c|c|c|c|c|}
\hline \multirow[b]{3}{*}{ Taxon } & \multicolumn{4}{|c|}{ Initial litter nutrients } & \multicolumn{4}{|c|}{ Initial litter $\mathrm{C}$ fractions (\%) } & \multirow[b]{3}{*}{ Lignin: $\mathrm{N}$} & \multirow[b]{3}{*}{ Lignin:P } & \multirow{2}{*}{\multicolumn{2}{|c|}{$\begin{array}{l}\text { Litter solubility } \\
\quad(\mathrm{mg} \mathrm{C} / \mathrm{g})\end{array}$}} \\
\hline & $\mathrm{N}$ & $\mathrm{P}$ & & & Cell & Hemi- & & & & & & \\
\hline & $(\%)$ & $(\mathrm{mg} / \mathrm{g})$ & $\mathrm{C}: \mathrm{N}$ & $C: P$ & soluble & cellulose & Cellulose & Lignin & & & Initial & Total \\
\hline Bulk litter & 0.85 & 0.28 & 43.63 & 1319.8 & 46.36 & 8.46 & 21.98 & 23.20 & 27.23 & 823.6 & 13.33 & 27.80 \\
\hline Brosimum & 1.06 & 0.60 & 45.11 & 800.7 & 25.81 & 11.39 & 25.91 & 36.89 & 34.78 & 617.4 & 2.66 & 7.19 \\
\hline Cecropia & 1.00 & 0.24 & 37.77 & 1581.6 & 30.30 & 10.06 & 26.10 & 33.55 & 33.41 & 1398.9 & 6.27 & 12.27 \\
\hline Ceiba & 1.38 & 0.87 & 31.36 & 495.5 & 60.33 & 12.07 & 11.96 & 15.65 & 11.34 & 179.1 & 9.53 & 41.67 \\
\hline Huberodendron & 1.11 & 0.34 & 43.80 & 1427.0 & 43.33 & 10.72 & 11.91 & 34.04 & 30.64 & 998.4 & 9.64 & 25.82 \\
\hline Hyeronima & 1.23 & 0.83 & 38.09 & 565.8 & 33.70 & 7.20 & 19.79 & 39.31 & 31.91 & 474.0 & 4.71 & 12.66 \\
\hline Inga & 2.28 & 0.76 & 18.99 & 571.6 & 40.27 & 11.45 & 21.92 & 26.37 & 11.57 & 348.3 & 11.90 & 24.31 \\
\hline Manilikara & 0.64 & 0.11 & 77.62 & 4382.7 & 52.76 & 10.16 & 17.11 & 19.97 & 31.39 & 1772.4 & 6.37 & 22.64 \\
\hline Pouteria & 0.90 & 0.24 & 55.09 & 2063.1 & 25.52 & 8.27 & 18.11 & 48.11 & 53.63 & 2008.2 & 5.71 & 18.52 \\
\hline Qualea & 0.61 & 0.18 & 68.64 & 2379.9 & 62.92 & 10.53 & 15.40 & 11.14 & 18.35 & 636.3 & 5.51 & 27.35 \\
\hline Schizolobium & 2.55 & 1.36 & 17.54 & 328.5 & 46.05 & 8.80 & 13.32 & 31.83 & 12.46 & 233.5 & 14.40 & 23.42 \\
\hline Symphonia & 1.54 & 0.32 & 30.57 & 1464.9 & 47.82 & 18.64 & 20.69 & 12.85 & 8.33 & 399.0 & 4.36 & 10.38 \\
\hline Mean & 1.26 & 0.51 & 42.35 & 1448.4 & 42.93 & 10.65 & 18.68 & 27.74 & 25.42 & 824.1 & 7.87 & 21.17 \\
\hline
\end{tabular}



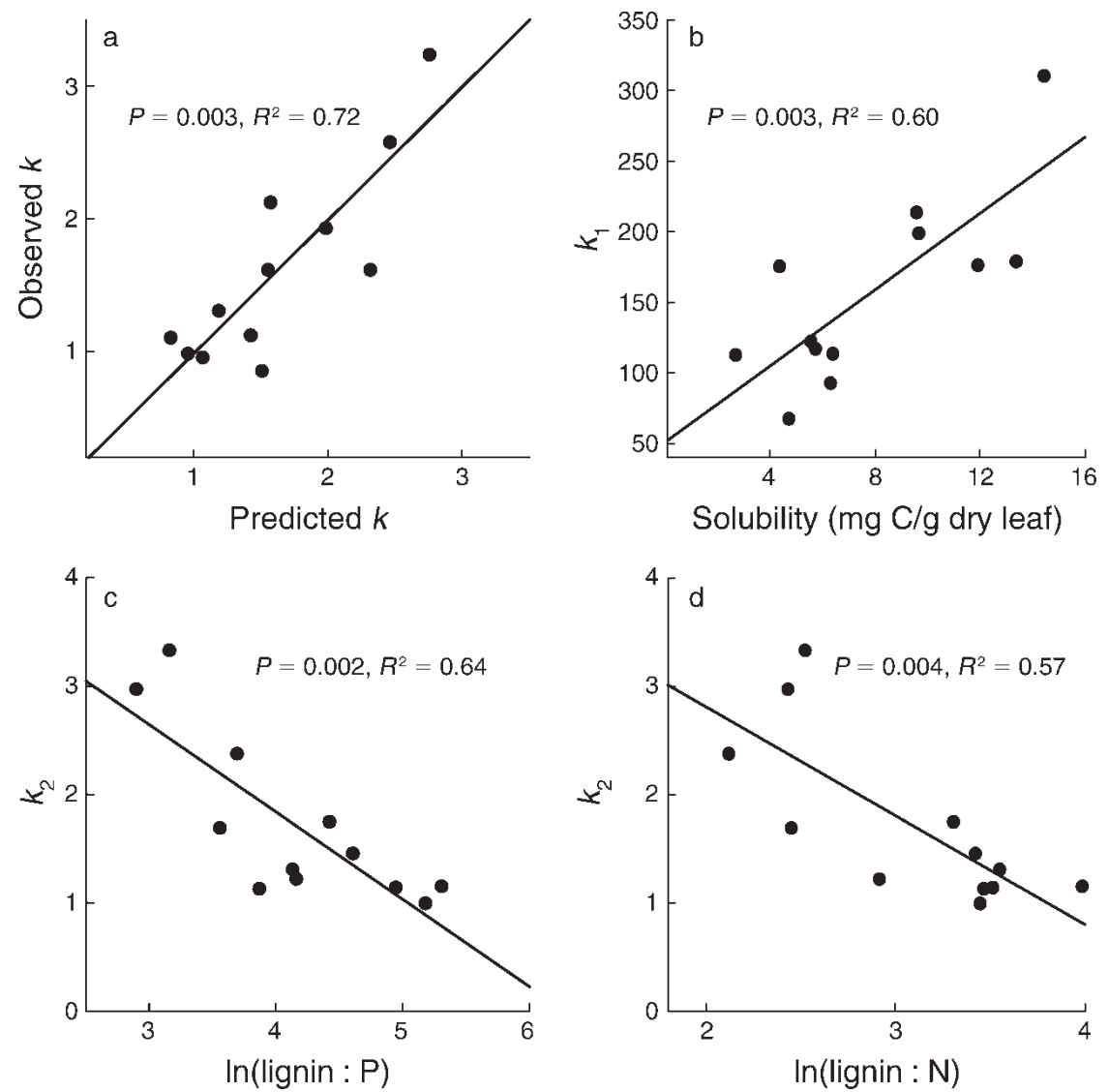

FIG. 2. Regression analyses of factors affecting litter decomposition. (a) Observed vs. predicted decomposition constants ( $k$ values) from multiple linear regression with backward elimination using litter solubility and lignin:P as predictors. (b) Initial litter solubility was the best predictor for initial decomposition rates $\left(k_{1}\right)$. (c, d) Lignin:P and lignin:N both predicted secondary decomposition rates $\left(k_{2}\right)$.

observed $k_{2}$ values $\left(R^{2}=0.64, P=0.002\right.$; Fig. $\left.2 \mathrm{c}\right)$; lignin: $\mathrm{N}$ also accounted for a significant amount of the variation in $k_{2}\left(R^{2}=0.57, P=0.004\right.$; Fig. $\left.2 \mathrm{~d}\right)$.

\section{Throughfall manipulation}

Rainout shelters significantly reduced the amount of throughfall reaching the forest floor. Total throughfall in the manipulation plots was significantly lower than in the control plots, and the 25\% and 50\% manipulations were also significantly different from one another $\left(F_{2,5}=45.46\right.$, $P<0.001$; Fig. 3). A rain gauge located in an adjacent clearing recorded $4540 \mathrm{~mm}$ of precipitation over the 230 $\mathrm{d}$ of litter decomposition, while control plots received $4490 \pm 212 \mathrm{~mm}$ throughfall (mean $\pm \mathrm{SE}$ ) over the same time period. Plots with $25 \%$ throughfall exclosures received $3160 \pm 140 \mathrm{~mm}$ and $50 \%$ plots received 2190 $\pm 154 \mathrm{~mm}$ of throughfall, representing a $30 \%$ and $51 \%$ reduction in actual throughfall, respectively.

Reducing throughfall led to significantly lower rates of litter mass loss at all stages of decomposition, but we observed no significant treatment $\times$ species interaction (Table 3). Mean litter turnover time, the estimated time to $95 \%$ decomposition, increased from $1.64 \mathrm{yr}$ in control plots to $1.99 \mathrm{yr}$ and $2.06 \mathrm{yr}$ in plots receiving $25 \%$ and

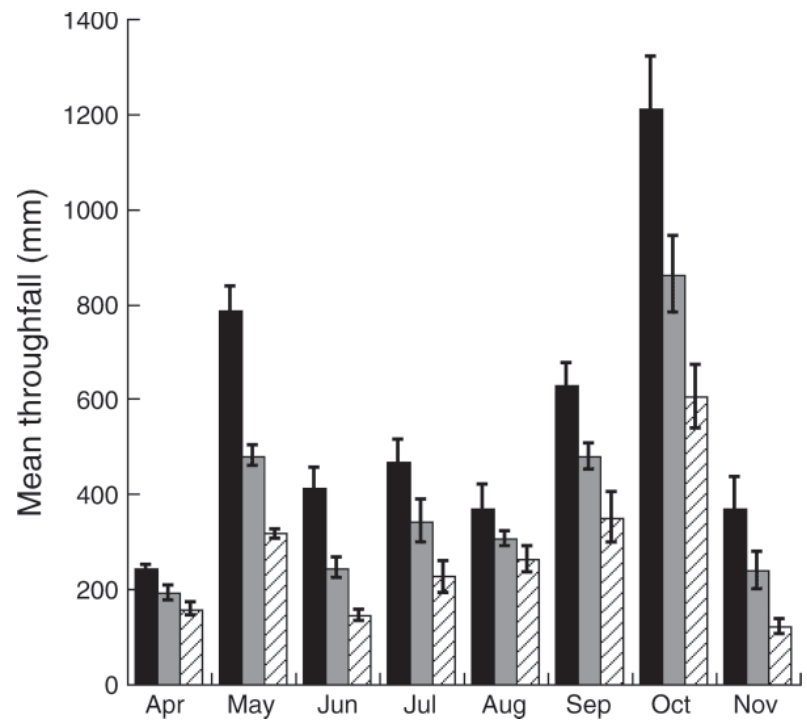

FIG. 3. Total throughfall (mean and SE) reaching the soil surface in control (black bars), 25\% plots (gray bars), and 50\% plots (hatched bars) collected from lysimeters at the soil surface over the course of the decomposition experiment. 
TABle 3. Two-way ANOVA for precipitation treatment and species effects on litter decomposition.

\begin{tabular}{|c|c|c|c|c|c|c|c|}
\hline \multirow[b]{2}{*}{ Source of variation } & \multirow[b]{2}{*}{ df } & \multicolumn{2}{|c|}{$k$} & \multicolumn{2}{|c|}{$k_{1}$} & \multicolumn{2}{|c|}{$k_{2}$} \\
\hline & & $F$ & $P$ & $F$ & $P$ & $F$ & $P$ \\
\hline Treatment & 2 & 23.41 & $<0.001$ & 6.072 & $<0.001$ & 7.58 & 0.001 \\
\hline Species & 5 & 210.3 & $<\mathbf{0 . 0 0 1}$ & 73.06 & 0.004 & 43.73 & $<\mathbf{0 . 0 0 1}$ \\
\hline Treatment $\times$ species & 10 & 1.42 & 0.18 & 0.73 & 0.694 & 1.83 & 0.07 \\
\hline
\end{tabular}

Note: Significant effects at $P<0.05$ are in boldface, those at $P<0.10$ are in italics.

$50 \%$ reduction in throughfall, respectively. Decomposition constants for all species from both throughfall manipulations were significantly lower than control $k$ values (Tukey hsd, $P<0.001$ ), but $25 \%$ and $50 \%$ throughfall decomposition rates were not different from one another $(P=0.62)$. Initial litter decomposition constants from the $50 \%$ plots were significantly lower than control plots $(P=0.04)$, but $k_{1}$ values from $25 \%$ plots were not statistically different from either control or $50 \%$ plots $(P>0.42)$. Finally, $k_{2}$ values from both $25 \%$ and $50 \%$ reduction plots were significantly lower than controls $(P \leq 0.001)$, but not significantly different from one another $(P=0.61)$. To normalize species effects in the throughfall manipulation, we calculated response ratios for all decomposition constants by dividing mean $k$ values from treatment plots by control $k$ values (Fig. 4). Reducing throughfall to 3300 or $2200 \mathrm{~mm}$ led to declines in litter decomposition rates of $\sim 20 \%$.

\section{DisCUSSION}

As has been observed in many tropical forests, litter decomposition occurs very rapidly in this warm, wet ecosystem. The average decomposition rate for all species in this study was still faster than all but two (out of 52) observed $k$ values reported from tropical and temperate sites in the Long-term Intersite Decomposition Experiment (LIDET; Gholz et al. 2000). Moreover, the litter used in this experiment was of much lower quality than that used in the LIDET study (e.g., mean lignin: $\mathrm{N}$ of all species was more than five times higher in the present study). Our reported $k$ values are high, but comparable to those from other tropical ecosystems (reviewed in Aerts 1997). Cleveland and others (2006) reported much higher $k$ values from the same site, but for litter with much higher quality than was used in the present study.

We also observed a nearly fourfold variation in decomposition rates between species (Fig. 1, Table 1) that correlated with chemical and physical differences in litter quality. Similarly, large differences in decomposition rates among co-occurring species appear globally and are related to green leaf economics (Cornwell et al. 2008). Litter decomposition requires a variety of enzymes from multiple microbes to access a diverse suite of C-rich but nutrient-poor organic substrates. Thus, in a variety of ecosystems, rates of litter decomposition are positively related to initial litter nutrient availability ( $\mathrm{N}$ and $\mathrm{P}$ ) and negatively related to initial litter lignin (Melillo et al. 1982, Aerts 1997, Hobbie and Vitousek 2000). In this study, these same metrics of litter quality were predictive of litter decomposition rates, especially at later stages.

Climate is the most important regulator of litter decomposition (Aerts 1997, Gholz et al. 2000); but when climate conditions maximize potential decomposition, litter quality controls are enhanced, and our results suggest that $\mathrm{P}$ is an important component of litter quality in the tropics. We propose a two-stage model of litter decomposition (Swift et al. 1979, Loranger et al. 2002, Xu and Hirata 2005; similar to the first two stages of the Adair et al. [2008] model) for wet tropical forests, in which initial litter solubility controls early rates of decomposition and more standard metrics of litter quality (i.e., lignin:P) appear to control rates of secondary decomposition. This model explains a significant amount of our observed variation in $k$ values (Fig. $\left.2 \mathrm{a} ; R^{2}=0.72\right)$. We stress that the variation in litter decomposition rates among neighboring species in this ecosystem was high. Past work shows that a diversity of plant strategies to balance trade-offs between leaf

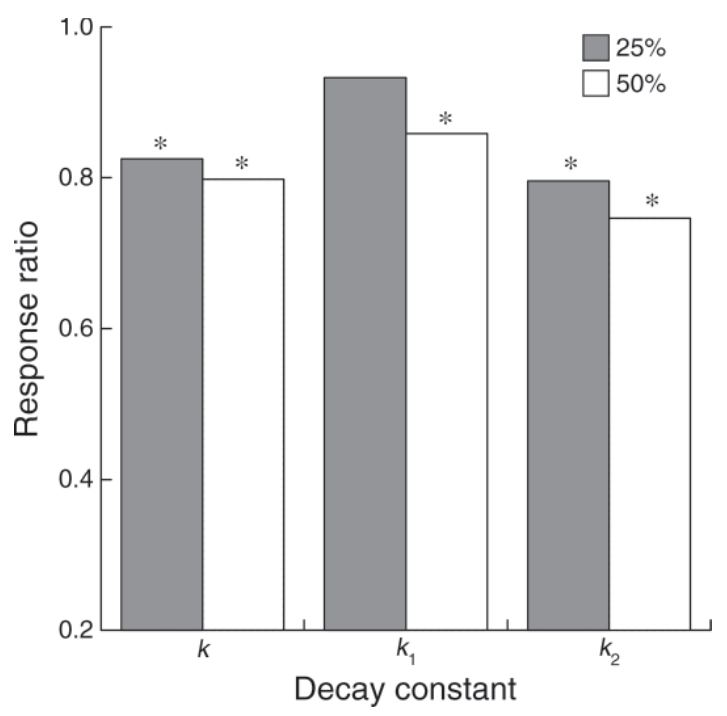

FIG. 4. Response ratios of litter decomposition to $25 \%$ and $50 \%$ reduction in throughfall calculated by dividing mean treatment by mean control decomposition rate constant. Reducing throughfall significantly slowed all stages of decomposition (ANOVA, $P<0.005$ ). Asterisks indicate treatments with significant differences from control decomposition rates (Tukey's B post hoc test, $P<0.05$ ). 
productivity, longevity, and defense, tree growth, and nutrient acquisition translates into biogeochemical diversity that affects rates of litter decomposition at local and global scales (see Santiago 2007, Cornwell et al. 2008). Such species effects are likely to be especially pronounced in tropical forests, where high species diversity leads to enormous local- and regional-scale variation in canopy chemistry (Townsend et al. 2008).

One goal of this experiment was to test the hypothesis that high litter solubility, combined with high precipitation, drives significant mass loss through leaching of DOM from the litter layer in wet tropical forests (Cleveland et al. 2006). Our results suggest that species-specific initial litter solubility strongly regulates the initial rates of decomposition; among all species, litter mass loss ranged from $<8 \%$ to $>40 \%$ over the first 50 days of this experiment and initial litter solubility explains much of this variation (Fig. 2b). Thus, pulses of soluble organic matter that reach surface soils, where they are an important driver of soil respiration and other biogeochemical processes (Cleveland and Townsend 2006, Wieder et al. 2008; C. C. Cleveland et al., unpublished manuscript), appear to be strongly mediated by species-specific differences in litter chemistry. Neff and Asner (2001) noted that losses of DOM from the litter layer do not represent an immediate loss of carbon from the ecosystem. Rather, leached C is transferred to soils, where past work in this site has shown that its residence time and likely fate are strongly determined by the P content of the DOM and/or the soil (Cleveland and Townsend 2006, Wieder et al. 2008). Thus, while physical leaching alleviates nutrient constraints on initial litter decomposition, subsequent biological processes needed to regenerate soluble $\mathrm{C}$ fractions and/or directly mineralize remaining leaf litter may be subject to stronger nutrient limitation.

While measures of $\mathrm{N}$ availability are especially important in predicting rates of litter decomposition in temperate ecosystems (Parton et al. 2007), the apparent $\mathrm{P}$ controls over litter decomposition in this study warrant discussion. Lowland tropical forests growing on highly weathered soils are characterized by low soil P availability, high foliar and litter N:P ratios, and possible P limitation of ANPP (Vitousek 1984, Vitousek and Farrington 1997, Reich and Oleksyn 2004). Numerous lines of evidence demonstrate that $\mathrm{P}$ is an important regulator of soil processes at this site (Cleveland et al. 2002, Cleveland and Townsend 2007, Reed et al. 2007, Wieder et al. 2008). Phosphorus availability appears to control rates of litter decomposition here (Fig. 2c) and in other tropical sites (Aerts 1997, Hobbie and Vitousek 2000, Santiago 2007), although direct fertilization experiments do not necessarily confirm this conclusion (McGroddy et al. 2004, Cleveland et al. 2006, Kaspari et al. 2008).

Potential P limitation of litter decomposition has important implications for nutrient availability, ecosystem productivity, and $\mathrm{C}$ balance. For example, slow decomposition of P-poor litter could exacerbate $\mathrm{P}$ limitation (Hobbie 1992); alternately, rapid decomposition of high quality, P-rich litter could relax P limitation and maintain relatively high ANPP (Kitayama et al. 2004). At our site, soil respiration also increases with $P$ availability (Cleveland and Townsend 2006), and species delivering P-rich DOM stimulate higher rates of soil respiration (Wieder et al. 2008), thus dissolved $\mathrm{P}$ delivered during litter decomposition may have important implications for system C balance. Given the high heterogeneity of foliar $\mathrm{P}$ content in tropical forests (Townsend et al. 2007), P limitation of decomposition could exist from local (e.g., below individual tree canopies) to regional scales, influencing both plant productivity and heterotrophic soil respiration.

A second goal of this experiment was to directly test how variation in throughfall affected litter decomposition. We found that any reduction in precipitation slowed total decomposition ( $k$ ) by $\sim 20 \%$ (Fig. 4). These findings contrast to those of Schuur (2001), who concluded that increasing MAP above $\sim 2500 \mathrm{~mm}$ slows decomposition by increasing periods of soil anoxia and slowing rates of microbial activity and nutrient mineralization. Under this model, suppressed rates of nutrient turnover could create a negative feedback, whereby low soil nutrient availability leads to declines in litter quality and productivity in very wet sites (Schuur 2003). Reduced soil $\mathrm{O}_{2}$ availability may indeed be important in some high-precipitation forests (Silver et al. 1999). We observe periods of soil anoxia at our site during the wettest month of year that have important implications for soil nutrient cycling; however, these anoxic periods occur when forest litter mass is at its annual minimum (W. R. Wieder, unpublished data) and likely have negligible effects on annual rates of litter decomposition. Instead, the physical effects of high precipitation and highly soluble leaf litter combined to promote high rates of decomposition that appeared to increase with throughfall inputs well above $2500 \mathrm{~mm} / \mathrm{yr}$.

Taken as a whole, our results suggest that widely used predictors of litter decomposition based on chemical quality are still useful in wetter tropical forests and that these wet systems also require an understanding of litter solubility to best predict rates of decomposition. Leaching of soluble DOM clearly represents an important control of litter decomposition at our site, and results from our precipitation manipulation suggest this conclusion may be broadly applicable to forests receiving $>2500 \mathrm{~mm}$ MAP, which includes a significant fraction of tropical forests (Zaks et al. 2007). Thus, litter decomposition driven via leaching of DOM may be an important, understudied characteristic of many tropical systems.

Finally, our results also suggest that the wettest of lowland forests may sustain some of the highest rates of litter turnover on earth. This implies that any reductions of MAP as a result of climate change would likely slow rates of decomposition, unless litter quality concurrently 
increased. Yet, given the substantial importance of species-level traits in driving rates of litter decomposition, any predictions of climate effects will need to account for possible changes in species composition and their associated effects on litter chemistry. These data highlight the need for further research into interactions between climate, species composition, and litter quality to improve predictions of how litter decomposition and nutrient cycling may respond to rapid and ongoing human disturbances to the tropical biome.

\section{ACKNOWLEDGMENTS}

We thank H. Michaud and M. Jimenez of the Drake Bay Wilderness Camp for providing field access and logistical support in Costa Rica. We also thank Francisco Campos and the Organization for Tropical Studies (OTS) and the Ministerio de Ambiente y Energia (MINAE) in Costa Rica for assisting with research permits and logistics. Walkam Combranero Castro assisted with field sampling, and Rachel Kimmel and Mysti Martin helped with all phases of the laboratory work. Thanks to Nataly Ascarunz, Margie Krest, and two anonymous reviewers for providing helpful comments on this manuscript. This work was supported by the National Science Foundation (NSF Grant DEB-0515744 to A. R. Townsend and C. C. Cleveland and an NSF Graduate Research Fellowship to W. R. Wieder).

\section{Literature Cited}

Adair, E. C., W. J. Parton, S. J. Del Grosso, W. L. Silver, M. E. Harmon, S. A. Hall, I. C. Burkes, and S. C. Hart. 2008. Simple three-pool model accurately describes patterns of long-term litter decomposition in diverse climates. Global Change Biology 14:2636-2660.

Aerts, R. 1997. Climate, leaf litter chemistry and leaf litter decomposition in terrestrial ecosystems: a triangular relationship. Oikos 79:439-449.

Allison, S. D., and P. M. Vitousek. 2004. Extracellular enzyme activities and carbon chemistry as drivers of tropical plant litter decomposition. Biotropica 36:285-296.

Austin, A. T., and P. M. Vitousek. 2000. Precipitation, decomposition and litter decomposability of Metrosideros polymorpha in native forests on Hawai'i. Journal of Ecology 88:129-138.

Bern, C. R., A. R. Townsend, and G. L. Farmer. 2005. Unexpected dominance of parent-material strontium in a tropical forest on highly weathered soils. Ecology 86:626632.

Clark, D. A. 2004. Sources or sinks? The responses of tropical forests to current and future climate and atmospheric composition. Philosophical Transactions of the Royal Society B 359:477-491.

Clark, D. A., S. Brown, D. W. Kicklighter, J. Q. Chambes, J. R. Thomlinson, J. Ni, and E. A. Holland. 2001. Net primary production in tropical forests: an evaluation and synthesis of existing field data. Ecological Applications 11: 371-384.

Cleveland, C. C., S. C. Reed, and A. R. Townsend. 2006. Nutrient regulation of organic matter decomposition in a tropical rain forest. Ecology 87:492-503.

Cleveland, C. C., and A. R. Townsend. 2006. Nutrient additions to a tropical rain forest drive substantial soil carbon dioxide losses to the atmosphere. Proceedings of the National Academy of Sciences (USA) 103:10316-10321.

Cleveland, C. C., A. R. Townsend, and S. K. Schmidt. 2002. Phosphorus limitation of microbial processes in moist tropical forests: evidence from short-term laboratory incubations and field experiments. Ecosystems 5:680-691.
Cornwell, W. K., et al. 2008. Plant species traits are the predominant control on litter decomposition rates within biomes worldwide. Ecology Letters 11:1065-1071.

Currie, W. S., and J. D. Aber. 1997. Modeling leaching as a decomposition process in humid montane forests. Ecology 78:1844-1860.

Dixon, R. K., S. Brown, R. A. Houghton, A. M. Solomon, M. C. Trexler, and J. Wisniewski. 1994. Carbon pools and flux of global forest ecosystems. Science 263:185-190.

Field, C. B., M. J. Behrenfeld, J. T. Randerson, and P. Falkowski. 1998. Primary production of the biosphere: integrating terrestrial and oceanic components. Science 281: 237-240.

Gholz, H. L., D. A. Wedin, S. M. Smitherman, M. E. Harmon, and W. J. Parton. 2000. Long-term dynamics of pine and hardwood litter in contrasting environments: toward a global model of decomposition. Global Change Biology 6:751-765.

Hobbie, S. E. 1992. Effects of plant-species on nutrient cycling. Trends in Ecology and Evolution 7:336-339.

Hobbie, S. E. 1996. Temperature and plant species control over litter decomposition in Alaskan tundra. Ecological Monographs 66:503-522.

Hobbie, S. E., and L. Gough. 2004. Litter decomposition in moist acidic and non-acidic tundra with different glacial histories. Oecologia 140:113-124.

Hobbie, S. E., P. B. Reich, J. Oleksyn, M. Ogdahl, R. Zytkowiak, C. Hale, and P. Karolewski. 2006. Tree species effects on decomposition and forest floor dynamics in a common garden. Ecology 87:2288-2297.

Hobbie, S. E., and P. M. Vitousek. 2000. Nutrient limitation of decomposition in Hawaiian forests. Ecology 81:1867-1877.

Kappelle, M., C. Marco, H. Acevedo, L. González, and H. Monge. 2003. Ecosistemas del área de conservación Osa (ACOSA). Instituto Nacional de Biodiversidad, San Jose, Costa Rica.

Kaspari, M., M. N. Garcia, K. E. Harms, M. Santana, S. J. Wright, and J. B. Yavitt. 2008. Multiple nutrients limit litterfall and decomposition in a tropical forest. Ecology Letters 11:35-43.

Kitayama, K., S. Aiba, M. Takyu, N. Majalap, and R. Wagai. 2004. Soil phosphorus fractionation and phosphorus-use efficiency of a Bornean tropical montane rain forest during soil aging with podozolization. Ecosystems 7:259-274.

Kuo, S. 1996. Phosphorus. Pages 869-919 in D. L. Sparks, editor. Methods of soil analysis. Part 3. Chemical methods. Soil Science Society of America, Madison, Wisconsin, USA.

Loranger, G., J. F. Ponge, D. Imbert, and P. Lavelle. 2002. Leaf decomposition in two semi-evergreen tropical forests: influence of litter quality. Biology and Fertility of Soils 35:247252.

Martinelli, L., M. Piccolo, A. Townsend, P. Vitousek, E. Cuevas, W. McDowell, G. Robertson, O. Santos, and K. Treseder. 1999. Nitrogen stable isotopic composition of leaves and soil: tropical versus temperate forests. Biogeochemistry 46:45-65.

McGroddy, M. E., W. L. Silver, and J. R. Cosme de Oliveira. 2004. The effect of phosphorus availabililty on decomposition in a seasonal lowland Amazonian forest. Ecosystems 7: 172-179.

Meehl, G. A., et al. 2007. Global climate projections. Pages 747-843 in S. Solomon, D. Qin, M. Manning, Z. Chen, M. Marquis, K. B. Averyt, M. Tignor, and H. L. Miller, editors. Climate Change 2007: the physical science basis. Contribution of Working Group I to the Fourth Assessment Report of the Intergovernmental Panel on Climate Change. Cambridge University Press, New York, New York, USA.

Meentemeyer, V. 1978. Macroclimate and lignin control of litter decomposition rates. Ecology 59:465-472.

Melillo, J. M., J. D. Aber, and J. F. Muratore. 1982. Nitrogen and lignin control of hardwood leaf litter decomposition dynamics. Ecology 63:621-626. 
Neff, J. C., and G. P. Asner. 2001. Dissolved organic carbon in terrestrial ecosystems: synthesis and a model. Ecosystems 4: $29-48$.

Nepstad, D. C., et al. 2002. The effects of partial throughfall exclusion on canopy processes, aboveground production, and biogeochemistry of an Amazon forest. Journal of Geophysical Research: Atmospheres 107. [doi: 10.1029/ 2001JD000360]

Olson, J. S. 1963. Energy storage and the balance of producers and decomposers in ecological systems. Ecology 44:322-331.

Parton, W., W. L. Silver, I. C. Burke, L. Grassens, M. E. Harmon, W. S. Currie, J. Y. King, E. C. Adair, L. A. Brandt, S. C. Hart, and B. Fasth. 2007. Global-scale similarities in nitrogen release patterns during long-term decomposition. Science 315:361-364.

Potter, C. S., and S. A. Klooster. 1997. Global model estimates of carbon and nitrogen storage in litter and soil pools: response to changes in vegetation quality and biomass allocation. Tellus Series B, Chemical and Physical Meteorology 49:1-17.

Quesada, F. J., Q. Jimenez, N. Zamora, R. Aguilar, and J. González. 1997. Árboles de la Peninsula de Osa. First edition. Instituto de Biodiversidad, Heredia, Costa Rica.

Reed, S. C., C. C. Cleveland, and A. R. Townsend. 2007. Controls over leaf litter and soil nitrogen fixation in two lowland tropical rain forests. Biotropica 39:585-592.

Reich, P. B., and J. Oleksyn. 2004. Global patterns of plant leaf $\mathrm{N}$ and $\mathrm{P}$ in relation to temperature and latitude. Proceedings of the National Academy of Sciences (USA) 101:1100111006.

Saleska, S. R., et al. 2003. Carbon in Amazon forests: unexpected seasonal fluxes and disturbance-induced losses. Science 302:1554-1557.

Santiago, L. S. 2007. Extending the leaf economics spectrum to decomposition: evidence from a tropical forest. Ecology 88: $1126-1131$

Scherer-Lorenzen, M., J. L. Bonilla, and C. Potvin. 2007. Tree species richness affects litter production and decomposition rates in a tropical biodiversity experiment. Oikos 116:21082124.

Schuur, E. A. G. 2001. The effect of water on decomposition dynamics in mesic to wet Hawaiian montane forests. Ecosystems 4:259-273.

Schuur, E. A. 2003. Productivity and global climate revisited: the sensitivity of tropical forest growth to precipitation. Ecology 84:1165-1170.
Silver, W. H., A. E. Lugo, and M. Keller. 1999. Soil oxygen availability and biogeochemistry along rainfall and topographic gradients in upland wet tropical forest soils. Biogeochemistry 44:301-328.

Swift, M. J., O. W. Heal, and J. M. Anderson. 1979. Decomposition in terrestrial ecosystems. University of California Press, Berkeley, California, USA.

Tian, H. Q., J. M. Melillo, D. W. Kicklighter, A. D. McGuire, J. V. K. Helfrich, B. Moore, and C. J. Vorosmarty. 1998. Effect of interannual climate variability on carbon storage in Amazonian ecosystems. Nature 396:664-667.

Townsend, A. R., G. P. Asner, and C. C. Cleveland. 2008. The biogeochemical heterogeneity of tropical forests. Trends in Ecology and Evolution 23:424-431.

Townsend, A. R., C. C. Cleveland, G. P. Asner, and M. M. C. Bustamante. 2007. Controls over foliar N:P ratios in tropical rain forests. Ecology 88:107-118.

Vitousek, P. M. 1984. Litterfall, nutrient cycling, and nutrient limitation in tropical forests. Ecology 65:285-298.

Vitousek, P. M., and H. Farrington. 1997. Nutrient limitation and soil development: experimental test of a biogeochemical theory. Biogeochemistry 37:63-75.

Vitousek, P. M., and J. R. L. Sanford. 1986. Nutrient cycling in moist tropical forest. Annual Review of Ecology and Systematics 17:137-167.

Vitousek, P. M., D. R. Turner, W. J. Parton, and R. L. Sanford. 1994. Litter decomposition on the Mauna Loa environmental matrix, Hawai'i: patterns, mechanisms, and models. Ecology 75:418-429.

Wieder, R. K., and S. J. Wright. 1995. Tropical forest litter dynamics and dry season irrigation on Barro Colorado Island, Panama. Ecology 76:1971-1979.

Wieder, W. R., C. C. Cleveland, and A. R. Townsend. 2008. Tropical tree species composition affects the oxidation of dissolved organic matter from litter. Biogeochemistry 88: $127-138$.

Xu, X. N., and E. J. Hirata. 2005. Decomposition patterns of leaf litter of seven common canopy species in a subtropical forest: N and P dynamics. Plant and Soil 273:279-289.

Yavitt, J. B., R. K. Wieder, and S. J. Wright. 1993. Soil nutrient dynamics in response to irrigation of a Panamanian tropical moist forest. Biogeochemistry 19:1-25.

Zaks, D. P. M., N. Ramankutty, C. C. Barford, and J. A. Foley. 2007. From Miami to Madison: investigating the relationship between climate and terrestrial net primary production. Global Biogeochemical Cycles 21. [doi: 10.1029/ 2006GB002705] 